MARTA ŚLEZIAK

ORCID: 0000-0003-4297-7728

Uniwersytet Wrocławski, Polska

IZABELA OLSZEWSKA

ORCID: 0000-0001-9150-0980

Uniwersytet Gdański, Polska

\title{
Analiza wydawnictw efemerycznych - ujęcie lingwistyczne
}

\section{Wydawnictwa efemeryczne - ramy definicyjne}

W dotychczasowych badaniach nad wydawnictwami efemerycznymi nie uwzględniano dostatecznie potencjału językowego czy - szerzej - komunikacyjnego druków ulotnych. Wynika to nie tylko z interdyscyplinarności, która wpisana jest w specyfikę heterogenicznego zbioru efemer, lecz także z rozbieżności definicyjnych. W terminologii międzynarodowej wydawnictwa efemeryczne znane są jako non-book (także: non-printed; ephemeral; ephemera) materials i oznaczają drobne krótkotrwałe dokumenty życia codziennego ${ }^{1}$. Z bibliologicznego punktu widzenia, akcentującego rodzaje, gatunki i odmiany druków ulotnych i okolicznościowych (por. Migoń 2006:17), drukami efemerycznym są na przykład ulotki, broszury czy plakaty, ale też karty menu, zaproszenia i wizytówki - wszystko to, co wyprodukowano z myślą o aktualnej, bieżącej sytuacji. Dwuczłonowe określenie wydaje się jednak nieekonomiczne z uzualnego punktu widzenia i zarówno w literaturze światowej, jak i w społecznym obiegu najbardziej rozpowszechnione jest pojęcie ephemera, oznaczające pozycje kolekcjonerskie o krótkim i do-

1 Dosł. minor transient documents of everyday life (Rickards 2000:v). W innych językach nazwy omawianej kategorii również zawierają w sobie ulotność i krótkie trwanie, por. niem. Flugschriften, Flugblätter; franc. éphémères. 
raźnym przeznaczeniu. Wykorzystywany w definicji angielski rzeczownik items ${ }^{2}$ ma szerszy zakres niż leksem druki, dlatego określa się nim nie tylko materiały piśmienne, lecz także utrwalone na nośnikach niepapierowych takie przedmioty, jak naszywki, medale, taśmy filmowe, klisze. W rozpowszechnieniu terminu ephemera niewątpliwy udział miał jeden $\mathrm{z}$ najbardziej znanych propagatorów wiedzy o efemerach, brytyjski kolekcjoner, pisarz i grafik Maurice Rickards. To z jego inicjatywy w 1975 roku powstało brytyjskie The Ephemera Society (mające swoje bliźniacze stowarzyszenia w USA i Australii), które regularnie, począwszy od głośnej wystawy w 1975 roku, wydaje magazyn The Ephemerist. W 2000 roku ukazał się ilustrowany zbiór gromadzonych i opisywanych przez niego materiałów - monumentalna „The Encyclopedia of Ephemera”3.

W polszczyźnie określenie efemeryczny częściej jest kojarzone z efemerydami - czasopismami niesystematycznymi, krótkotrwałymi, jednodniowymi (STM 2006:49), albo z epitetem określającym (w bardziej lub mniej metaforycznym ujęciu) cechę czegoś lub kogoś. W Narodowym Korpusie Języka Polskiego rekord wyszukań określenia efemeryczny i jego derywatów to 169 akapitów, z czego wszystkie przedstawiają konteksty literackie i publicystyczne, które odnoszą się do znaczenia cechy określanej jako efemeryczna (efemeryczny 'szybko przemijający, krótkotrwały') ${ }^{4}$. W odniesieniu do publikacji określenie efemeryczne funkcjonuje w kolokacji wydawnictwa efemeryczne, które są synonimem zadomowionego na gruncie polskim określenia druki ulotne i okolicznościowe. Nazywane są one często także materiałami (drukami, publikacjami) niekonwencjonalnymi, nieksiążkowymi bądź akcydensami (Firlej-Buzon 2013:10-11, Muszkowski 1951/2015:169).

Druki ulotne i okolicznościowe są częścią zróżnicowanego zbioru pod nazwą dokumenty życia społecznego, w nomenklaturze bibliotecznej częściej są obecne pod postacią skrótowca DŻS. Dokumenty życia społecznego to „materiały biblioteczne o charakterze informacyjnym, normalizacyjnym, propagandowym, reklamowym, które są wynikiem działalności społecznej instytucji lub organizacji, posiadają krótkotrwałą wartość użytkową (służą doraźnej potrzebie), odzwier-

2 "Collectable items that were originally expected to have only short-term usefulness or popularity” - definicja ze słownika oksfordzkiego Lexico: https://www.lexico.com/definition/ephemera (dostęp: 12.03.2020).

${ }^{3} \mathrm{O}$ tym, jak bardzo interdyscyplinarny jest to zbiór, świadczy grono osób, które zostały zaproszone do tworzenia encyklopedii. Byli wśród nich historycy, historycy sztuki, graficy, filologowie języków klasycznych i nowożytnych, literaturoznawcy, kulturoznawcy, bibliografowie, wydawcy, kolekcjonerzy, eksperci z brytyjskich ośrodków akademickich, muzeów i bibliotek naukowych (Firlej-Buzon 2013:19, Rickards 2000:vi-vii).

${ }^{4}$ W NKJP w sąsiedztwie tego określenia pojawiają się m.in. rzeczowniki: gazeta, rzeczywistość, generacja, partia, sztuka, postać, wspomnienia, epizod, środowisko, moda. Zbieżny sposób konceptualizacji pojęcia widać w określeniu sztuka efemeryczna (np. performance), również zawartym wśród rekordu 169 cytatów, http://www.nkjp.uni.lodz.pl (dostęp: 12.03.2020). 
ciedlają przejawy współczesnego życia, na przykład prospekty, plakaty, cenniki, ulotki, księgi adresowe, telefoniczne" (PSB 2011:70).

Biblioteczne działy DŻS gromadzą nie tylko druki czy dokumenty, ale również przedmioty i obiekty zapisane na rozmaitych nośnikach, a także wytwory muzyczne. Skrótowe i poręczne określenie „DŻS-y” może jednak brzmieć nazbyt enigmatycznie, wręcz branżowo. $Z$ kolei nieduża popularność w polszczyźnie skrótowego (bez wydawnictwa) określenia efemera może wynikać z trzech powodów: 1. wcześniejszego usankcjonowania nazw druki ulotne oraz dokumenty życia społecznego; 2. zagospodarowania nazwy efemera przez określenie z dziedziny biologii ; 3. trudności fleksyjnych - pojęcie efemera intuicyjnie kategoryzuje się w liczbie mnogiej (tak jak licea, muzea) i może nastręczać trudności przy chęci zamiany na formę singularną.

Najczęściej więc słyszy się po prostu o drukach ulotnych, choć zarówno to pojęcie, jak i kategoria nadrzędna, dokumenty życia społecznego, mogą się wydawać niewystarczające, jeśli chcemy potraktować je możliwie szeroko - mocno konotują bowiem piśmienność, dokumentarność, formę drukowaną. Mając to na uwadze, decydujemy się na stosowanie pojęć efemera - efemery (singularis - pluralis) w odniesieniu do całego, bardzo zróżnicowanego zbioru. Czynimy tak z dwóch powodów. Po pierwsze dlatego, że ta para terminologiczna ma szerszy zakres definiendum i wydaje się najlepszym rozwiązaniem zwłaszcza w przypadku materiałów z przewagą kodu wizualnego nad słownym. Po drugie, aby oswoić pojęcie efemera, rozpowszechnione na gruncie międzynarodowym, a w polszczyźnie wciąż przypisywane wąskiej grupie przekazów. Nie rezygnujemy oczywiście z zamiennego stosowania pojęcia druki ulotne (w kontekście materiałów drukowanych).

\section{Efemery jako tekst i przedmiot badań}

Efemery są wykorzystywane w badaniach przedstawicieli rozmaitych dyscyplin ${ }^{6}$. Pojawiają się głównie w pracach bibliologów oraz kolekcjonerów i archiwistów, którzy podejmują rozważania nad poszczególnymi typami tego rodzaju materiałów (differentia specifica) oraz nad specyfiką całego zbioru (genus proximum) ${ }^{7}$. Znacznie częściej efemery stają się przedmiotem analiz jako teksty znaczące, informujące o czymś, będące świadectwem czasów lub wydarzeń, stanowiące ciekawy materiał egzemplifikacyjny. Wykorzystywane są między innymi w badaniach

\footnotetext{
${ }^{5} \mathrm{~W}$ słowniku pod red. Witolda Doroszewskiego efemery występują tylko w liczbie mnogiej - efemery blp biol. geogr. „krótko żyjące istoty żywe, które przystosowały się do nie sprzyjających warunków klimatycznych”, https://sjp.pwn.pl/doroszewski/efemery;5425213.html (dostęp: 12.03.2020).

${ }^{6}$ O badaniach nad drukami ulotnymi, przede wszystkim w odniesieniu do opracowań anglosaskich, pisze Aneta Firlej-Buzon (2013:11-13 - tekst i przypisy).

7 Por. np. Migoń (2006), Firlej-Buzon (2013), Rickards (2000).
} 
historyków, językoznawców, socjologów, historyków sztuki, komunikologów. Ze względu na ogromny podzbiór, jaki tworzą, osobne długie listy opracowań można by dopisać do każdego gatunku, który wchodzi w skład dokumentów życia społecznego. W publikacjach, w których tworzą one materiał badawczy, autorzy nie zawsze odwołują się do relacji hiperonimicznej, na użytek artykułu o ściśle zarysowanym temacie wystarczające jest bowiem zdefiniowanie samego gatunku (jak plakat, afisz, klepsydra, kartka pocztowa, wlepka i wiele, wiele innych).

W spektrum zainteresowania lingwistów efemery znalazły się przede wszystkim jako nośniki treści politycznych i propagandowych (Kamińska-Szmaj 2001:178-187) oraz reklam komercyjnych i społecznych (Grębowiec 2017). Stały się obiektem badań w kontekście wpływu na pamięć kulturową (Baliński 2019, Lukas 2019, Turska 2019, Kwiatkowska 2019a, Damps 2019, Taborska 2019, Filar 2019). Na wąskim materiale badawczym analizowano druki nieczęste w refleksji naukowej, na przykład klepsydry (Śleziak 2018). W wymienionych pracach zwracano szczególną uwagę na instrumentarium językowe i stylistyczne, które wykorzystywali nadawcy druków. O językowym kształcie wydawnictw efemerycznych wspominają też badacze zajmujący się tymi nośnikami z bibliologicznego punktu widzenia ${ }^{8}$.

Jak wielu dziedzin życia dotyczą efemery, tak liczne są opracowania, które koncentrują się na określonych funkcjach lub tematyce wydawnictw tego typu. Niezależnie od tematyki badacze zwracają uwagę na język, który jest nośnikiem znaczeń, sensów, wartości. Jednak kształt językowy jest często pobocznym obszarem refleksji nad efemerami - zwykle towarzyszy nadrzędnemu tematowi (reklama, propaganda, zmiany społeczne itp.). Językowa organizacja tekstów efemerycznych jest zagadnieniem wciąż nieopracowanym, a usystematyzowanie efemer ze względu na strukturę tekstu stanowi wyzwanie badawcze. Ponieważ cechą dystynktywną efemer jest to, że powstają w konkretnym i doraźnym celu, lingwistyczny opis gatunków efemerycznych korzystałby z narzędzi genologii tekstów użytkowych (zob. Wojtak 2008) i z narzędzi pragmatyki ${ }^{9}$. Można też zauważyć, że niektóre gatunki, ze względu na dużą powszechność i wyrazistość formy (na przykład plakat, manifest), są często uwzględniane w opracowaniach, inne natomiast funkcjonują niemal wyłącznie w publikacjach niszowych lub zbiorach kolekcjonerskich (na przykład karty menu, nalepki na bagaż). Dlatego w niniejszym artykule koncentrujemy się na całościowym, tekstualnym wymiarze efemer, dostrzegając potrzebę ich lingwistycznego ujęcia. Punkt ciężkości w opisie efemer jest wówczas położony nie na ukazanie sposobu, w jaki tekst druku

${ }^{8}$ Por. artykuły w zbiorze „Druki ulotne i okolicznościowe - wartości i funkcje” (Migoń/Skalska-Zlat/Żbikowska-Migoń 2006).

9 Pragmalingwistyczną analizę wybranych dokumentów życia społecznego przeprowadziła Aneta Kwiatkowska, pracując nad gdańskimi efemerami z okresu Wolnego Miasta Gdańska. Jako metodę badaczka przyjęła analizę deixis, co dało bardzo ciekawe wnioski dotyczące kreowania ról społecznych oraz sposobu opisu czasu i miejsca w wybranym do badań materiale (Kwiatkowska 2019b). 
ulotnego wpływa na postrzeganie świata zewnętrznego, ale na zwrócenie uwagi, jak na kształt językowy efemery oddziałuje rzeczywistość pozajęzykowa. Ujęcie diachroniczne pozwoliłoby ponadto ukazać wpływ kontekstu (społecznego, politycznego, historycznego) na ewolucję wzorca gatunkowego.

Wszystkie efemery są bowiem tekstami, w których szczególnie intensyfikuje się rola kontekstu. Naturalne dla badaczy komunikologów jest stwierdzenie, że kontekst jest składnikiem struktury tekstu (Witosz 2011:25), jednak nabiera ono jeszcze mocniejszego wyrazu w przypadku efemer, których cechami dystynktywnymi są między innymi: poruszanie tematów życia publicznego i codziennych potrzeb, aktualność, okazjonalność, masowość (Migoń 2006:15-16). Nie ulega wątpliwości, że efemery przynależą do przestrzeni publicznej, ożywiają ją (Murphy/O'Driscoll 2013:8). Dzieje się tak nie tylko z powodu miejsca, w których są pokazywane czy dystrybuowane, ale również ze względu na poruszaną w nich tematykę, osobę nadawcy i odbiorcy. Dla tekstu efemerycznego przestrzeń publiczna staje się więc znaczącym kontekstem, polem interakcji, który nadaje pojedynczej efemerze znaczenie. Widać to zwłaszcza w przestrzeni miast, które ,wchłaniają teksty” (Sawicka 2012:29) i w których obfitość (,przerost semiozy” - Rewers 2008:19) krzyżujących się znaków wynika między innymi z większego nagromadzenia takich form, jak graffiti, reklamy, plakaty, szyldy, neony. Tekst jest strukturą werbalno-wizualną, więc aby właściwie odczytywać znaczenie tych tekstów, nie sposób rozdzielić warstwy wizualnej od warstwy językowej (Poprawa 2020, Rewers 2008:20).

Do prawidłowego odczytania znaczenia efemery niezbędne jest potraktowanie jej jako tekstu złożonego z kodu słownego i wizualnego, silnie zanurzonego w przestrzeni, w jakiej powstała (kontekst) ${ }^{10}$.

\section{Model Linguera}

Jako badaczki zajmujące się na co dzień użytecznością druków ulotnych w lingwistyce dostrzegamy potrzebę stworzenia spójnego modelu analizy pojedyncze-

\footnotetext{
${ }^{10}$ Murphy i O’Driscoll na przykładzie ballad postulują rekonstrukcję pełnych znaczeń efemer, pisząc, że częste współcześnie odseparowanie (np. w kolekcjach muzealnych czy bibliotecznych, a także w dyscyplinach uniwersyteckich) form tekstowych od wizualnych nie służy odczytaniu znaczenia całości (Murphy/O’Driscoll 2013:10-21). Aby wyzyskać bogactwo sensów, proponują holistyczne i interdyscyplinarne odczytanie efemer (,This group of ballads, intriguing in themselves, provides a useful testing ground for the development of a truly interdisciplinary approach: an adequate interpretation requires a wealth of different information, all brought to bear at the same time" [Murphy/O’Driscoll 2013:20]). W literaturze językoznawczej holistyczny sposób odczytywania przekazów jest częstą praktyką, pozwalającą ukazać wielość znaczeń. Dobrymi przykładami są chociażby: analiza multimodalna plakatu (Winiarska 2016), analiza semiotyczna reklam (Piekot 2016), analiza fasetowa przekazów prasowych (Wilczewski 2013). Niemożność oddzielenia od siebie tekstu i obrazu w lingwistycznej analizie dyskursu celnie pokazał Jacek Szczepaniak, zestawiając punkty widzenia najważniejszych (w odniesieniu do analizy dyskursu) badaczy (Szczepaniak 2017).
} 
go tekstu efemerycznego. Model jest instrukcją, zgodnie z którą każdy, kto styka się z efemerą, będzie mógł krok po kroku odczytywać jej sensy. Chciałybyśmy, aby stał się uniwersalnym narzędziem wyławiania z tekstu najważniejszych znaczeń. Motywacją do podjęcia tej problematyki - i odpowiedzi na pytanie, czy każda efemera może być przeanalizowana według tego samego schematu - jest rodząca się w trakcie dyskusji akademickich potrzeba ukazania złożoności, jaką charakteryzują się efemery, oraz możliwego potratowania ich jako punktu wyjścia do wielu interesujących analiz lingwistycznych. Modelowi roboczo nadałyśmy nazwę „Linguera”, aby połączyć dwa kluczowe pojęcia: język i efemera.

Przystępując do odczytywania efemery, w pierwszej kolejności zwracamy uwagę na (1) otoczenie, czyli kontekst społeczny, polityczny i historyczny. Ma to szczególne znaczenie zarówno w odniesieniu do efemer „mocnych”, rzucających się w oczy w przestrzeni komunikacyjnej (jak na przykład plakaty, afisze), jak i mniej eksponowanych w przestrzeni publicznej (na przykład karty menu) oraz zupełnie drobnych (na przykład odręczne marginalia). Sformułowanie cech kontekstu pozwoli określić, w jakiej rzeczywistości pozajęzykowej jest zanurzony komunikat. Pomocne mogą być tutaj odpowiedzi na pytania o czas historyczny, kulturę polityczną, reżim, ustrój, wolność słowa. Nie bez znaczenia jest również nośnik, na którym powielono przekaz, oraz to, czy pojawił się w szerokiej przestrzeni publicznej (afisze na słupach, parkanach), czy wąskiej (ulotka konspiracyjna kolportowana $\mathrm{w}$ tajemnicy). Wszystkie te elementy mogą pomóc w odpowiedzi na pytanie, $\mathrm{z}$ jaką (ewentualną) perswazją mamy do czynienia w tekście i w jaki sposób może ona wpłynąć na znaczenie całości.

Drugim krokiem jest (2) ustalanie tożsamości, a więc odpowiedź na pytania o czas, w którym tekst powstał, miejsce, do którego się odnosi (niekoniecznie zbieżne z tym, gdzie go stworzono), oraz wydarzenie, którego dotyczy. Te trzy informacje można przedstawić na podstawie trójkąta - nazwijmy go „trójkątem efemerycznym”. Przykładem tekstów ukazujących zasadność skrupulatnego zwrócenia uwagi na te elementy są na przykład plakaty z hasłami politycznymi, które na pierwszy rzut oka dotyczą wydarzenia „tu i teraz”, lecz zawierają w sobie - zamierzoną bądź nie - intertekstualność.

Trzeci krok to określenie (3) charakteru komunikatu - gatunku, stylu, rejestru. Część efemer już na pierwszy rzut oka będzie zdradzać przynależność formalną, czy to za sprawą charakterystycznych cech typograficznych (na przykład klepsydra, list gończy), czy słów-kluczy w miejscach strategicznych (,Wezwanie”; „Obwieszczenie”; „Poszukiwany!”). Wybór wzorca może być spójny ze stylem treści (na przykład autentyczne klepsydry), ale nie musi (na przykład wtedy, gdy korzysta się ze stylizacji). Określenie dominanty gatunkowej i stylistycznej pozwoli przejść do kolejnych kroków i zbadać: (4) głębię formy (rodzaj layoutu, fontu, sposoby delimitacji tekstu, relacje między obiektami tekstowymi, rolę grafiki itp.) oraz (5) głębię treści, szczegółowo wchodząc w kwestie stylistyczne, leksykalne, pojęciowe itp. 
Wymieniona sekwencja działań pozwoli dość szczegółowo i syntetycznie scharakteryzować tekst jako obiekt zanurzony w znaczącym kontekście. Następnie, po uporządkowaniu kwestii prymarnych, którym służyło pięć pierwszych kroków, można przystąpić do (6) projektowania mapy analitycznej. Powinny się w niej znaleźć dwie ważne kwestie: informacja o celach badawczych i wybór narzędzi, które będą dominantą naszych badań.

W dalszej części artykułu przedstawiamy użyteczność modelu „Linguera”. Kolejne punkty odpowiadają omówionym etapom zarysowanej metody i mogą być przyczynkiem do pogłębionej analizy. Do badań wybrany został spójny tematycznie zbiór 50 wydawnictw ulotnych z okresu Wolnego Miasta Gdańska (1920-1939), obejmujący między innymi foldery turystyczne, ulotki reklamowe, zaproszenia, druki informujące o bieżących wydarzeniach politycznych i kulturalnych ${ }^{11}$.

\section{Zarys analizy}

\subsection{Otoczenie efemeryczne}

Jako otoczenie efemeryczne rozumiemy kontekst społeczno-polityczno-historyczny, w którym powstały analizowane teksty. Wolne Miasto Gdańsk (WMG) było autonomicznym miastem-państwem, funkcjonującym w latach 1920-1939 pod protektoratem Ligi Narodów. Miało swój hymn, flagę, godło oraz konstytucję. Była to przestrzeń ścierania się wpływów polskich i niemieckich, a obie społeczności konkurowały z sobą na wielu płaszczyznach: w gospodarstwie, polityce, religii, a także kulturze. $Z$ czasem tendencja ta nie tylko się nasiliła, lecz także przybrała formę swoistej dominacji kultury niemieckiej nad innymi:

Najliczniejszą grupą narodowościową w Gdańsku, jak i w całym Wolnym Mieście, byli Niemcy. Większość z nich to ludność od dawna mieszkająca na terenach włączonych w granice WMG. Drugą grupę gdańskich Niemców stanowiła ludność napływowa: głównie urzędnicy, dawni wojskowi oraz działacze polityczni powiązani z Rzeszą i od niej uzależnieni. Ogółem [...] w Wolnym Mieście mieszkały 348493 osoby narodowości niemieckiej [...]. Polacy byli następną pod względem liczbowym grupą narodowościową w WM Gdańsku (Cieślak red. 1999:30-32).

Konsekwencją faworyzowania kultury niemieckiej na obszarze WMG było istnienie w przestrzeni publicznej wielu tekstów niemieckojęzycznych, w tym wy-

11 Wszystkie cytaty pochodzą z tekstów druków ulotnych z okresu Wolnego Miasta Gdańska, znajdujących się w zbiorach Biblioteki Gdańskiej PAN (sygnatura zbioru: Odk. 4727/5; od $240554^{\circ}$, P1/1939, P5/1933, 4666/15, 4703/15, 4675/15. 
dawnictw efemerycznych. Aspiracją autorów (często anonimowych) było, poza przekazem informacji, także kreowanie wspólnej tożsamości społecznej - poprzez nawiązywanie do wpływów kultury niemieckiej, odwołania do przeszłości czy pielęgnowanie pamięci o historii miasta i okolic.

Metodologiczna próba analizy lingwistycznej wydawnictw efemerycznych na przykładzie okresu WMG wydaje się zasadna, gdyż teksty te idealnie ukazują rolę, wpływ i tym samym wagę efemer - od przekazu neutralnego komunikatu, poprzez integrację społeczności konkretnego kręgu kulturowego, do manipulacji społecznej i propagandy politycznej. W efemerach WMG widoczne jest zatem przejście z kategorii mikro, to jest dotyczącej konkretnej grupy społecznej (z zagospodarowaną przestrzenią społeczną, polityczną, gospodarczą, kulturową), do kategorii makro, to jest wychodzącej poza przestrzeń jednej społeczności (uruchamiającej mechanizmy wpływu na sytuację także innych grup).

\subsection{Trójkąt efemeryczny}

Istotnym aspektem $w$ badaniach nad efemerami jest uwzględnienie cech typowych dla tego gatunku: kategorii czasu (diachronia i synchronia), miejsca (z ważną opozycją nasze, na przykład Heimat, versus obce) oraz charakteru wydarzenia (sprawy bieżące a okazjonalność). Nazywamy je trójkątem efemerycznym. Są to kategorie występujące praktycznie w każdym rodzaju efemer, tworzące kolejny ważny krok w analizie lingwistycznej.

Kategoria czasu

W analizie temporalnej wydawnictw efemerycznych uwzględnić należy zarówno płaszczyznę synchroniczną (współczesną odbiorcy lub będącą projekcją przyszłości), jak i diachroniczną (historyczną, archiwalną) przekazu.

- Perspektywa synchroniczna

Temporalność analizy wydawnictw efemerycznych w kontekście synchronicznym wpisana jest w naturę komunikatu, jaki zostaje dystrybuowany odbiorcy. Zawiera konkretną lub przybliżoną informację o czasie wydarzenia, wyrażanym godziną, dniem tygodnia lub miesiąca, rzadziej datą roczną. Przekaz zawiera odpowiedzi na typowe dla okoliczników czasu pytania: Kiedy? Jak długo? Jak często? Odkąd?

(1) Einladung zur Schau-Turn-Fest in Jaschkenthal am 11. Juni [Zaproszenie na obchody Święta Gimnastyki w Jaśkowej Dolinie]. 
(2) Das Weltbad Zoppot liegt an der Ostsee, 20 Minuten von der alten ehrwürdigen Hansastadt Danzig entfernt [Światowej sławy kurort Sopot leży nad Morzem Bałtyckim, 20 minut od starego, szacownego miasta hanzeatyckiego - Gdańska].

Informację dotyczącą czasu wyrazić można także za pomocą nazwy wydarzenia - to typowe działanie dla powtarzających się kulturowo wydarzeń, na przykład świąt, urodzin słynnych postaci lub innych, ważnych dla danej społeczności obchodów (na przykład Pfingstveranstaltungen - obchody Zielonych Świątek).

- Perspektywa diachroniczna

Temporalność w kontekście diachronicznym to przede wszystkim odwoływanie się do przeszłości przestrzeni efemerycznej. W przypadku analizowanego materiału może polegać na wspominaniu Hanzy, na przykład w komunikatach informacyjnych (adres: Badeanstalt „Hansabad” am Hansaplatz [Kąpielisko Hanza przy Placu Hanzy] lub reklamowych, turystycznych i politycznych (Handelsstadt von hervorragender Bedeutung [Miasto handlowe o wybitnym znaczeniu] $)^{12}$. Widoczne już przy okazji Hanzy odwołania do historii niemieckiej oraz nobliwości Gdańska to kolejna strategia integrująca społeczność WMG przez podkreślanie ciągłości tradycji kulturowej:

(3) Durch ernste mittelalterliche Tore geht es zu der Langen Brücke, dem schönsten malerischen Ufer an der Mottlau, an dem sich die Haltestellen der Dampfer reihen [Droga prowadzi poprzez średniowieczne wrota do Długiego Pobrzeża, najbardziej malowniczego brzegu nad Motławą, przy którym jeden za drugim przycumowane są statki parowe].

(4) Zwischen Krantor und Langem Markt haben die Jahrhunderte eine steinerne Chronik in einzigartigen Gassenzeilen aufgezeichnet: herbe Gotik der Ordensritterzeit, reiche Renaissance im Goldschmuck des Gesteins, prunkendes Barock [Pomiędzy żurawiem a Długim Targiem wieki odcisnęły kamienną Kronikę w jedynych w swoim rodzaju uliczkach: surowy gotyk z okresu zakonu rycerskiego, bogaty renesans w złoceniach kamieni czy przepych baroku].

Kategoria miejsca

Poza kategorią czasu równie istotnym elementem analizy wydawnictw efemerycznych jest kategoria miejsca. Miejsca są symbolami danego regionu, na stałe kojarzą się z topografią konkretnej przestrzeni, jak na przykład Rathaus [ratusz], Marienkirche [Kościół Mariacki], Danziger Hafen [Port Gdański], Danziger

12 Tłumaczenie przykładów DW z j. niemieckiego - I.O. 
Krantor [Gdańska Brama Żuraw], Zoppoter Waldoper [Opera Leśna w Sopocie]. $\mathrm{W}$ odniesieniu do efemer można mówić o takich kategoriach, jak:

- neutralność przestrzenna - informacje o regionie przekazywano klasycznie, w sposób neutralny, za pomocą okolicznika miejsca, odpowiadając na pytania: Gdzie? Skąd? Dokąd? Którędy? Często identyfikowano przestrzeń za pomocą głównych kierunków geograficznych - w przypadku WMG były to konsekwentnie wschód, zachód, północ. Wiązało się to być może z faktem, że przed pierwszą wojną światową Gdańsk był stolicą Prus Zachodnich, a po Wielkiej Wojnie stał się, na mocy traktatu wersalskiego, wyłącznie stolicą Wolnego Miasta Gdańska: Wie die Westpreußen sprechen [Jak się mówi w Prusach Zachodnich], Die Siedlungen Westpreußens und ihre Entwicklung aus deutschen Urformen [Osady Prus Zachodnich i ich rozwój z prawzoru niemieckiego], Das Verhältnis der Westpreußen zum Meere und zur Künste [Stosunek mieszkańców Prus Zachodnich do morza i sztuki];

- wartościowanie topograficzne - przestrzeń geograficzna, która jest składnikiem większości efemer. Wartościowanie tego typu dotyczy w pierwszej kolejności efemer reklamowych, turystycznych, kulinarnych i politycznych. Wartościowaniu podlega zarówno region gdański, jak i konkretne miejsca przestrzeni miejskiej, ważne dla lokalnej społeczności, stanowiące rozpoznawalne i integralne symbole miejsca. W przypadku WMG zabieg ten widoczny jest głównie w warstwie leksykalnej tekstu, na przykład w słownictwie wartościującym lub jednoznacznie kojarzącym się z danym kręgiem kulturowym, jak słowa kluczowe charakteryzujące i określające niemieckość: deutsch [niemiecki], Deutschtum [niemczyzna], Danzig [Gdańsk], Heimat [mała ojczyzna].

(5) Immer wieder blickt man auf den mächtig emporstrebenden Turm der Marienkirche [Zewsząd widoczna jest potężna wieża Kościoła Mariackiego].

(6) Eines der Straßentore an der Langen Brücke ist weltbekannt geworden: das Krantor [Jedna z bram ulicznych przy Długim Pobrzeżu zyskała światową sławę - Brama Żuraw].

Wartościowanie (zazwyczaj pozytywne w odniesieniu do swojego regionu) zarówno topografii WMG, jak i konkretnych miejsc, symboli na mapie miasta-państwa, odbywa się również za pomocą stopniowania przymiotników, a także przy użyciu rzeczowników czy wyrażeń przyimkowych, na przykład allerschönste Lage Danzigs [przepiękne położenie Gdańska], in wundervoller Gegend [w cudownej okolicy], das herrliche Landschaftsbild [wspaniałe pejzaże], prächtiger Strand [wspaniała plaża]: 
(7) Ostseebad und Luftkurort liegt $8 \mathrm{~km}$ von Danzig entfernt, an der Eisenbahnlinie Danzig-Stettin-Berlin in wundervoller Gegend [Kurort nadbaltycki położony jest w cudownej okolicy, $8 \mathrm{~km}$ od Gdańska, wzdłuż linii kolejowej Gdańsk-Szczecin-Berlin].

Kolejną strategią wartościującą przestrzeń bywa także symbolika miejsca utrwalona w nazwach, głównie chrematonimach, Machandel ${ }^{13}$, Goldwasser ${ }^{14}$, Beischläge ${ }^{15}$ :

(8) Eine besondere Danziger Eigenart sind altanartige Vorbauten, 'Beischlag' genannt [Szczególną osobliwością Gdańska są altanopodobne przybudówki, zwane przedprożami].

(9) Immer wenn ich Danzig höre, denke ich an Lachs-Liköre [Zawsze, gdy słyszę słowo Gdańsk, myślę o likierach firmy Lachs].

\section{Kategoria wydarzenia}

Ostatnim wierzchołkiem trójkąta efemerycznego są wydarzenia rozmaitej wagi: cykliczne i okazjonalne, prywatne i państwowe, obchody świąt świeckich bądź religijnych, a także wydarzenia przynależące do sfery kulturalno-społecznej oraz politycznej. Rodzaj wydarzeń zapowiadanych przez efemery ukazuje - zwłaszcza po latach - do jakich wartości przywiązywano największą wagę, co było kultywowane, jak o tym pisano. Zbiór efemer WMG szczególnie uwypukla dużą rangę uroczystych jubileuszy, na przykład Deutschkundliche Woche ${ }^{16}$ (Tydzień Niemcoznawczy).

\subsection{Charakter komunikatu}

Komunikację za pomocą wydawnictw efemerycznych określić można jako proces, w którym treści mają głównie charakter krótkotrwały, przekazywane są za pomocą medium tekstu, potencjalnie w tym samym czasie, niebezpośrednio i jednostronnie wielu osobom, często będącym dla nadawcy zupełnie anonimowymi (por. Burger 2005:1). Podobnie w kwestii komunikacji masowej wypowiada się Kübler (2000:15), stwierdzając, że komunikacja medialna ma miejsce, gdy teksty/

\footnotetext{
13 Machandel - słynna wódka o jałowcowym smaku, produkowana od 1776 roku przez menonicką rodzinę Stobbe; uważany był za gdański trunek narodowy (zob. EG 2012:601).

14 Goldwasser -słynna wódka gdańska, zawiera charakterystyczne płatki złota (zob. EG 2012:346).

15 Przedproża - jeden z najbardziej charakterystycznych elementów gdańskich domów mieszczańskich i ulicy. Rodzaj ogrodzonego balustradą tarasu ze schodami i zejściem do piwnicy (zob. EG 2012:842-845).

16 Deutschkundliche Woche - wydarzenie kulturalno-społeczne, organizowane cyklicznie w latach 1921-1938, mające na celu konstruowania wspólnej tożsamości i pamięci niemieckiej społeczności gdańskiej (por. także Olszewska 2018).
} 
grafiki/obrazy/dźwięki przekazywane są anonimowo, w postaci kodu, lub jasno, symultanicznie bądź w odstępie czasowym i przestrzennym, jedno- lub dwustronnie, poszczególnemu odbiorcy lub wielu odbiorcom czy grupom społecznym.

Przykładem wydawnictw efemerycznych, w których zarówno odbiorca, jak i nadawca nie pozostają anonimowi, są: zaproszenia, informacje o świętach rodzinnych, listy handlowe, świadectwa ukończenia szkoły, dyplomy itp. Częściej, zwłaszcza gdy druk dystrybuowany jest na dużą skalę, odbiorca komunikatu jest anonimowy - ukazują to druki i foldery reklamowe, informacje handlowe, na przykład o zmianie adresu siedziby firmy lub sklepu, ulotki polityczne, plakaty, obwieszczenia, anonse, zaproszenia (koncerty, wiece polityczne, inauguracje).

Gdańskie wydawnictwa efemeryczne, jako materiały szerokiego rozpowszechniania, były tekstami wydawanymi w celach informacyjnych, reklamowych czy propagandowych. W związku $\mathrm{z}$ tym $\mathrm{w}$ analizowanych przekazach można wyróżnić następujące typy komunikowania:

- typ komunikowania informacyjnego, cechujący się przekazywaniem informacji, faktów, wiedzy w sposób obiektywny i rzeczowy, w niektórych przypadkach z wykorzystaniem technik wizualnych, takich jak zdobienia, rysunek, a także obrazek czy mapa. Teksty te cechować może też podniosły styl, podkreślający wagę przekazywanej informacji, a także formy grzecznościowe czy tłusty druk. Typ komunikowania informacyjnego znajdujemy szczególnie w takich efemerach, jak: zaproszenia, rachunki, pokwitowania, afisze, klepsydry;

- typ komunikowania perswazyjnego, to jest zachęcanie oraz nakłanianie odbiorcy do pewnych działań, których oczekuje nadawca komunikatu, stosując w tym celu przemyślaną argumentację oraz odpowiednio dobrane słownictwo. Informacja dotyczy konkretnych idei, wartości, przedmiotów czy postaw. Typ komunikowania perswazyjnego odnajdujemy zwłaszcza w efemerach reklamowych, handlowych, politycznych;

- typ komunikowania wizualnego, którego celem jest wywarcie na odbiorcy wrażenia estetycznego. Dominantą tego typu przekazów jest kod wizualny. Wiele z tych efemer ma dużą wartość kolekcjonerską, nieprzemijającą mimo upływu lat. Do tej grupy można zaliczyć plakaty i kartki pocztowe, ale też między innymi specjalnie zaprojektowane wizytówki, karty menu, znaczki pocztowe.

Należy podkreślić, że wyróżnione tutaj typy komunikatów wskazują na nadrzędną funkcję, jaką konkretnej efemerze przypisał jej nadawca (instytucja, organizacja, cech, urząd, partia polityczna itp.). W wielu przekazach efemerycznych wszystkie wymienione cechy się bowiem przenikają, tworząc mariaż właściwości, funkcji i celów komunikacyjnych.

\subsection{Głębia formy}

Ten krok uwzględnia przede wszystkim analizę formalną przekazu - w takich aspektach, jak layout, krój fontu, rodzaj nośnika (wielkość, czytelność, wyko- 
rzystanie oryginalnego materiału bądź nadpisywanie na materiale zastanym). W przypadku efemer szczególnie istotna jest multimodalność przekazu, obecność symbolu, ryciny, znaku, koloru, zdjęcia i innych elementów, które podkreślają efektywność i doniosłość komunikatu.

Interesujące, że niektóre efemery WMG miały nadrukowane pismo odręczne, nie maszynowe, co było częstym zabiegiem w przypadku między innymi zaproszeń, gdy chciano spersonalizować przekaz i skrócić dystans między nadawcą a odbiorcą. Ponadto znaczenie ma kolor - wielobarwność była domeną folderów reklamowych, skierowanych głównie do bogatszej klienteli. Jeśli na druku pojawiają się postacie, są to najczęściej osoby o smukłej, wysportowanej sylwetce i niebieskich oczach. Środowiska związane z niemieckim kręgiem kulturowym stosowały frakturę, rodzaj pisma jednoznacznie kojarzony z niemieckością. Niemalże we wszystkich efemerach WMG pojawiały się także symbole Gdańska (tak zwane Danziger Wahrzeichen [gdańskie symbole]): Żuraw, kościół Mariacki czy ratusz miejski).

\subsection{Głębia treści}

Zagłębiając się $\mathrm{w}$ treść efemery, należy uwzględnić wszelkie możliwe sposoby wyławiania sensów - zarówno tych wyrażanych eksplicytnie, jak i komunikowanych nie wprost, za pomocą celowego doboru zróżnicowanych środków wyrazu. Szczególną rolę będą tu więc odgrywały presupozycje, implikatury, środki stylistyczne i retoryczne, dobór środków leksykalnych i składniowych. Przy czym ważne, aby pamiętać - zwłaszcza gdy od wydanych efemer dzielą nas dziesiątki lat - o specyfice języka badanego okresu, tak aby to, co było zupełnie naturalne w badanym okresie, nie wydało się nietypowe i fałszywie znaczące.

W odniesieniu do efemer WMG można zauważyć, że agitacja niemieckiego kręgu kulturowego odbywa się za pośrednictwem tekstów niekoniecznie propagandowych (por. druki kulinarne czy turystyczne). Natomiast szczególnie w przypadku efemer politycznych (lecz nie tylko) można dostrzec klasyczne i wyrażone wprost elementy perswazji językowej, takie jak:

- pytania podkreślające dychotomię: Danzig deutsch oder polnisch? [Gdańsk niemiecki czy polski?];

- epitety: polnische Provokation [polska prowokacja], deutsche Männer [Niemcy], Danzig ist deutsch und bleibt deutsch! [Gdańsk jest niemiecki i pozostanie niemiecki], Es geht um unser deutsches Danzig [Chodzi o nasz niemiecki Gdańsk];

- metafory: Danzig - eine Königin der Ostsee [Gdańsk, królowa nad Bałtykiem], Danzig - Kleinod nordischer Städteschönheit [Gdańsk - klejnot nordyckiego piękna miasta];

- budowanie wspólnoty świata, wyrażane odniesieniami do ciągłości kultury niemieckiej, niemieckiego dziedzictwa materialnego i niematerialnego, na 
przykład za pomocą przymiotników: alt [stary], deutsch [niemiecki] oraz okoliczników miejsca i czasu, takich jak damals [wówczas], jahrhunderte lang [przez stulecia], hier [tutaj], por.:

(10) Ein Gang durch Danzigs alte Gassen und historische Bauten läßt das ewig deutsche Antlitz der einstigen Hansestadt in ihrer nordischen Schönheit wieder erstehen [Spacer starymi uliczkami Gdańska, pośród historycznych budowli, pozwala dostrzec wieczne niemieckie oblicze tego niegdysiejszego miasta hanzeatyckiego].

\section{Projektowanie mapy analitycznej. Podsumowanie}

Ostatnia część modelu zakłada projektowanie mapy analitycznej w odniesieniu do konkretnego zbioru efemer. Ważne jest, aby każdy badacz - po zebraniu informacji, do których prowadzą kolejne kroki metody - postawił pytanie o swoją rolę w prowadzonej analizie. Teraz staje się istotne, jaką reprezentuje dyscyplinę i co chce przez analizę osiągnąc. W przypadku druków z okresu WMG ważne było uwypuklenie perswazyjności przekazów. Odpowiedź na pytanie byłaby niepełna i w dużej mierze intuicyjna, jeśli wzięlibyśmy pod uwagę tylko środki językowe - bez zbadania kontekstu; tylko aspekt wizualny - bez dostrzeżenia relacji ze słowem.

Może nasunąć się pytanie, czy analiza ukierunkowana od razu na jeden cel, na przykład zbadanie roli nagłówków w efemerach, nie może odbyć się z pominięciem wcześniejszych etapów. Wydaje się to niemożliwe, jeśli z analizowanego materiału chcemy rzetelnie wyzyskać wszystkie znaczenia. Należy bowiem jeszcze raz podkreślić, że w przypadku efemer znaczący jest każdy szczegół. Kod wizualny i językowy trwale się przenikają, istotne jest otoczenie efemeryczne, ogromną rolę odgrywa kontekst, a treść i forma wpływają na całość przekazu.

Projekt modelu „Linguera”, zwracający uwagę na nierozerwalność formy i treści efemer, uwypuklający rolę kontekstu, tożsamość przekazu, istotę sprzężenia kodów, tworzy propozycję otwartą i uniwersalną. Może być traktowany jako badawcza inspiracja, punkt odniesienia, temat naukowej debaty. Ważne, by efemery stawały się częstym przedmiotem analiz lingwistycznych; wydają się bowiem materiałem zbyt bogatym i zróżnicowanym, aby ich sensy odkrywać wybiórczo.

\section{Bibliografia}

BaLiŃSKi Aleksander, 2019, Die verlorene Seele einer Stadt. Danzig zwischen der Freien Stadt und den Revolutionen 1848/1849, w: Studia Germanica Gedanensia 41, s. 217-226. 
Burger Harald, 2005, Mediensprache. Eine Einführung in Sprache und Kommunikationsformen der Massenmedien, Berlin/New York.

Cieślak Edmund (red.), 1999, Historia Gdańska, t. IV/2. 1920-1945, Sopot.

DAmps Ewelina, 2019, Die Danziger Theaterzettel aus der ersten Hälfte des 19. Jahrhunderts als kulturhistorische Dokumente, w: Studia Germanica Genanensia 41, s. 278-296.

Filar Magdalena, 2019, Stereotype von Polen im deutschen Weltbild des 19. Jahrhunderts. Eine ethnolinguistische Studie, w: Studia Germanica Genanensia 41, s. 330-340.

FirLej-Buzon Aneta, 2013, Druki ulotne i okolicznościowe jako źródła do badań dziejów i kultury Dolnego Śląska lat 1945-1956, Wrocław.

GRĘBOwIEC Jacek, 2017, Pragmatyka reklamy, Kraków.

KamiŃsKa-Szmaj Irena, 2001, Słowa na wolności, Wrocław.

KwiatKowska Aneta, 2019a, Die Danziger Werbemarken („Cinderella stamps”) aus den Jahren 1900-1939, w: Studia Germanica Genanensia 41, s. 264-277.

KwiatкowsKa Aneta, 2019b, Pragmalingwistyczna analiza dokumentów życia społecznego na przykładzie wybranych niemieckojęzycznych tekstów z okresu Wolnego Miasta Gdańska 1920-1939 (niepublikowana rozprawa doktorska, obroniona 9.09.2019 na Wydziale Filologicznym Uniwersytetu Gdańskiego).

KÜBLER Hans-Dieter, 2000, Mediale Kommunikation, Tübingen.

LuKAs Katarzyna, 2019, Die Hanse als instrumentalisierter Erinnerungsort in touristischen Flugschriften aus der Freien Stadt Danzig (1920-1939), w: Studia Germanica Genanensia 41, s. $227-246$.

Migoń Krzysztof, 2006, Bibliologia o drukach ulotnych i okolicznościowych, w: Migoń K./ Skalska-Zlat M./Żbikowska-Migoń A. (red.), Druki ulotne i okolicznościowe - wartości i funkcje. Materiały Międzynarodowej konferencji naukowej, Wojnowice, 8-10 października 2006, s. $9-19$.

Migoń Krzysztof / Skalska-Zlat Marta / ŻBiKowsKa-Migoń Anna (red.), 2006, Druki ulotne i okolicznościowe - wartości i funkcje. Materiały Międzynarodowej konferencji naukowej, Wojnowice, 8-10 października 2006.

MurPhy Kevin / O'Driscoll Sally, 2013, Introduction: „Fugitive Pieces” and „Gaudy Books”: Textual, Historical, and Visual Interpretations of Ephemera in the Long Eighteenth Century", w: Murphy K./O'Driscoll S. (red.), Studies in Ephemera. Text and Image in Eighteenth-Century Print, Lewisburg, s. 1-28.

Muszkowski Jan, 1951/2015, Życie książki. Edycja krytyczna na podstawie wydania z 1951 r., Czapnik G./Gruszka Z. (oprac.), Łódź/Warszawa.

OLszewsKa Izabela, 2018, Druk ulotny jako medium pamięci społecznej na przykładzie programu „Deutschkundliche Woche” z lat 1921-1938, w: Mape J./Wielądek K./Ovchinnikova L./Marzouka F. (red.), Socjolingwistyczne badania w teorii i praktyce. Ujęcie Interdyscyplinarne. t. 5, Gdańsk, s. 39-57.

Ріекот Tomasz, 2016, Mediacje semiotyczne. Słowo i obraz na usługach ideologii, Warszawa.

Poprawa Marcin, 2020, Przestrzenie słowno-obrazowe w propagandowych drukach ulotnych lat 1918-1939 - próba analizy w świetle lingwistyki tekstowej i teorii wizualności, w: Sztuka Edycji 1, s. $203-230$.

REwers Ewa, 2008, Miejskie laboratorium komunikacji transkulturowej, w: Jałowiecki B./Łukowski W. (red.), Szata informacyjna miasta, Warszawa.

RICKARDS Maurice, 2000, The Encyclopedia of Ephemera. A Guide to the Fragmentary Documents of Everyday Life for the Collector, Curator, and Historian, edited and completed by Michael Twyman, with the assistance of S. de Beaumont and A. Tanner, London.

SAwicka Grażyna, 2012, Miasto jako tekst, w: Święcicka M. (red.), Miasto. Przestrzeń zróżnicowana językowo, kulturowo i społecznie, Bydgoszcz. 
SzCZEPANIAK Jacek, 2017, Tekst (i) obraz w lingwistycznej analizie dyskursu", w: Socjolingwistyka 31, s. $7-20$.

ŚLEZIAK Marta, 2018, Klepsydry na tle innych tekstów pożegnalnych, Wrocław.

TABORSKA Katarzyna, 2019, Zur narrativ-bildenden Funktion von Ephemera im „Grenzgebiet des Augenblicks, w: Studia Germanica Genanensia 41, s. 317-329.

TuRsKa Marta, 2019, Danziger Weinpreislisten. Zum Text im urbanen Raum, w: Studia Germanica Genanensia 41, s. 247-263.

WiLCZEWSKi Michał, 2013, Analiza fasetowa tekstów prasowych jako metoda rekonstrukcji sposobów profilowania zdarzeń globalnych (na przykładzie polskich i amerykańskich wiadomości dotyczących operacji „Świt Odysei” w Libii), w: Zeszyty Prasoznawcze 2(214), s. 238-258.

WinIARSKA Justyna, 2016, Plakat jako przykład multimodalnego amalgamatu, w: LingVaria 2 (22), s. $43-55$.

Witosz Bożena, 2011, Interakcyjny model relacji gatunku i dyskursu w przestrzeni komunikacyjnej, w: Ostaszewska D. (red.), Gatunki mowy i ich ewolucja, t. 4. Gatunek a komunikacja społeczna, Katowice, s. 23-31.

WoJtak Maria, 2008, Genologia tekstów użytkowych, w: Ostaszewska D./Cudak R. (red.), Polska genologia lingwistyczna, Warszawa, s. 339-361.

\section{Słowniki i encyklopedie}

EG - Encyklopedia Gdańska, 2012, Gdańsk.

PSB - Czapnik G. / Gruszka Z. (oprac.), 2011, Podręczny słownik bibliotekarza, Warszawa.

STM - Pisarek W. (red.), 2006, Słownik terminologii medialnej, Kraków.

\section{Wykaz źródeł}

Wydawnictwa efemeryczne z Biblioteki PAN Gdańskiej o sygnaturach: Odk. 4727/5; Od $240554^{\circ}$, P1/1939, P5/1933, 4666/15, 4703/15, 4675/15.

\section{The analysis of ephemeral prints - a linguistic approach}

The aim of the paper is to present ephemeral printed texts as an object of a linguistic description as well as to submit the model of analysis in practice. Texts called as ephemera are usually an object of a non-linguistically targeted interdisciplinary approach, although ephemera, regardless of type and style, can be subject to the scheme of a linguistic analysis. The submitted Linguera model (lingua et ephemera) enables meticulous analysis of an ephemeral text followed by its detailed and accurate analysis. The model focuses on such aspects as the role of context, evaluative language, contents and form of ephemera, as well as analytical map designing. The proposal of analysis is presented on the material of the ephemera collection from the Free City of Danzig (1920-1939).

Keywords: ephemera, advertisement prints, linguistic analysis, context. 